ZOOLOGIA 32(5): 329-333, October 2015

http://dx.doi.org/10.1590/S1984-46702015000500001

\title{
The island rule in the Brazilian frog Phyllodytes luteolus (Anura: Hylidae): incipient gigantism?
}

\author{
Marcio Mageski ${ }^{1, *}$, Rodrigo B. Ferreira ${ }^{1}$, Paulo R. Jesus ${ }^{1}$, Larissa C. da Costa ${ }^{1}$, \\ James J. Roper ${ }^{1} \&$ Paulo D. Ferreira ${ }^{2}$
}

\author{
${ }^{1}$ Departamento de Ecologia de Ecossistemas, Universidade Vila Velha. Rua Comissário José Dantas de Melo 21, Boa Vista, \\ 29102-920 Vila Velha, ES, Brazil. \\ ${ }^{2}$ Departamento de Gemologia, Universidade Federal do Espírito Santo. Avenida Fernando Ferrari 514, Goiabeiras, \\ 29075-710 Vitória, ES, Brazil. \\ *Corresponding author. E-mail: marcioherpetologia@gmail.com
}

\begin{abstract}
The island rule suggests that, when mainland animals are isolated on islands, large animals tend to become smaller, while small animals tend to become larger. A small frog in eastern Brazil, Phyllodytes luteolus (Wied-Neuwied, 1824), is widely distributed in association with bromeliads. At the end of the last glaciation, parts of the mainland became islands due to rising sea levels, thereby isolating frog populations on these islands. If the island rule holds, we predicted that frogs on islands would tend to be larger than frogs on the mainland. We compared sizes (weight and length) of 30 randomly selected male frogs from the mainland with 30 from an island in the state of Espírito Santo, Brazil. We also sampled population density on the island and mainland because concurrent with changing sizes, depending on the causal relationship, density may also change. As predicted, island frogs tended to be larger (both in snout-vent length and weight) and were much more abundant. While not specifically addressed in this study, the absence of predators and interspecific competitors may explain both of these trends.
\end{abstract}

KEY WORDS. Bromeliad; amphibian; anuran; bromeligenous.

The island rule hypothesis suggests that after becoming isolated on islands, mainland animals tend to change in size, with smaller animals increasing and larger animals decreasing in size (FosTer 1964, VAN VALEN 1973). Originally described with mammals, the island rule has been expanded to include other vertebrates, because changes in size have been found in a variety of taxa (Lomolino 1985, Castellano \& Giacoma 1998, Clegg \& Owens 2002, Bовack \& GuYer 2003, Raia \& Meiri 2006, Wu et al. 2006, Price \& Phillimore 2007, Mathys \& Lockwood 2009, but see MeIrI 2007). Concomitantly, if body size increases then density may also increase (MCArTHUR et al. 1972, CASE 1975). The increase in size in smaller animals is generally attributed to the loss of predators on the islands or increased resource abundance (or both), which in turn, may be due to the loss of interspecific competitition (Lossos \& Ricklefs 2010). Because small amounts of gene flow would prevent heritable change in body size, reproductive isolation of the island populations is required for this process to occur (Hartl \& Clark 2006).

Population size may also change when a species is isolated on the island, but the exact relationship is unclear and depends upon the context (Lomolino 2005, Whittaker \& Fernandez-Palacios 2007, Lomolino et al. 2012). Relatively smaller population sizes are expected when competition is stronger
(McArthur et al. 1972), and the absence of competitors on islands may lead to increased population size (CASE 1975). However, this will depend upon resource availability and whether resources were the limiting factor on the mainland. Also, intraspecific competition may be stronger than interspecific, leading to a smaller population size when individuals increase in size. Thus, density compensation can lead to similar, increased or decreased density on islands (McArthur et al. 1972, Wright 1980, Whittaker \& Fernandez-Palacios 2007).

After the last glaciation, rising sea levels resulted in island formation along the Brazilian coast. Once isolated, island populations of animals that cannot disperse have remained reproductively and genetically isolated (BENZIE \& STODDART 1992). Thus, these islands are a natural testing-ground for the island rule, especially in frogs because salt water is a barrier to dispersal (Hopkins et al. 2014). At the same time, other sources of water are necessary and frogs that use those sources may tend to persist. Thus, water in tank bromeliads can favor persistence of those frog species that use them, if, on the island, bromeliads also persist and accumulate rain water. A frog that obligatorily uses bromeliads, Phyllodytes luteolus (Wied-Neuwied, 1824) is small (SVL: 24-25 mm, HADDAD et al. 2013), widely distributed in eastern Brazil (Frost 2013, Salles \& Silva-Soares 2010) and is

2015 | Sociedade Brasileira de Zoologia | www.sbzoologia.org.br | www.scielo.br/zool All content of the journal, except where identified, is licensed under a Creative Commons attribution-type BY. 
found, along with several species of tank bromeliads, on the mainland and on nearby islands (Регхото 1995, Oliveira et al. 2015). Thus, this species can offer a test of the island rule.

A variety of frogs obligatorily use bromeliads in Atlantic Forest and their sizes range from 14 to $49 \mathrm{~mm}$ (HADDAD et al. 2013). A change in size on islands may be due to a variety of factors, including changing pressures due to predation or competition, among others. This implies that other population parameters may also change on islands, such as population density. While density may change on islands relative to the mainland, complex dynamics and coexisting species must be understood to predict the direction of those changes (DiAmOND 1970a,b, McArthur et al. 1972, Case 1975, McGrady-Steed \& Morin 2000, Whittaker \& Fernandez-Palacios 2007). Regardless, if density remains constant and if the island rule holds, and size changes on islands, then biomass will also change. Thus, if the island rule holds, then other population parameters are expected to change as well, and understanding those changes can help in understanding causality in changing sizes.

Here, we describe a test of the island rule using frog populations on the mainland and nearby islands. Also, we compare abundance on the mainland and island as a first step in understanding what factors may influence the island rule. Because frogs are small, we predicted that size will increase. We also predict that density will change on the islands relative to the mainland because at least some of the potential predators and competitors are absent from the island.

\section{MATERIAL AND METHODS}

The mainland population was examined at Paulo César Vinha State Park, in Guarapari, in the state of Espírito Santo $\left(20.615^{\circ} \mathrm{S}, 40.418^{\circ} \mathrm{W}\right)$. We examine an island populations from one of five small islands that are about $200 \mathrm{~m}$ from one another and all are $\sim 3 \mathrm{~km}$ from the mainland $\left(20.613^{\circ} \mathrm{S}, 40.382^{\circ} \mathrm{W}\right.$, Fig. $1)$. Vegetation on the mainland and the island are very similar and includes the tank bromeliad Quesnelia quesneliana (Brongniart) L.B.Smith as an abundant bromeliad in both habitats.

Frogs were found by listening for vocalizations (CICHI et al. 2009, Silva-SoAres et al. 2010, Valdujo et al. 2011) and visually searching bromeliads on 6, 12 March and 2 April 2013 on the island and on 10, 25 March and 3 April 2013 on the mainland. During that time the climate was similar in both locations, with no rain and water was only available in the bromeliads. Searching and captures began at dusk ( 6:30 pm) when the first males began to call. We searched for frogs by first finding a patch within which a $5 \times 5$ m plot was able to be established in which bromeliads were distributed thoughout the plot. Upon finding a vocalizing frog within that patch, that location became the corner of the first $5 \times 5 \mathrm{~m}$ plot that was then oriented to include as many bromeliads as possible within the plot. In the plot, we counted all the tank bromeliads and all the frogs after exhaustive searching. After finishing

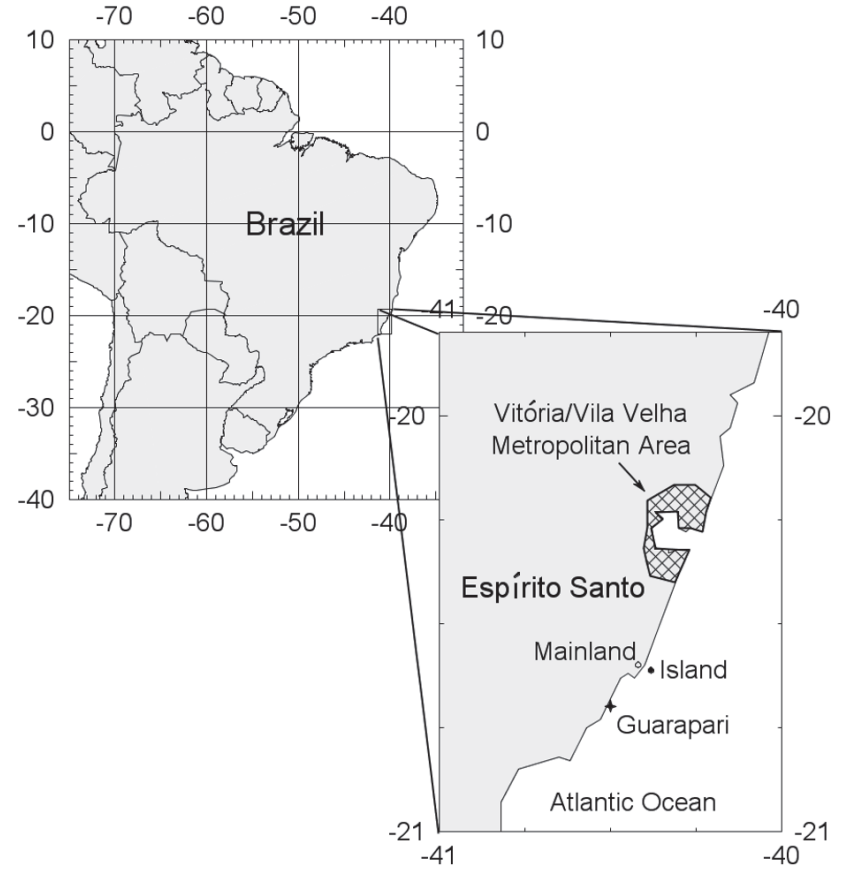

Figure 1. Map of the study area in Brazil, with detail of the sampling locations in the state of Espírito Santo, Brazil. The two small circles just north of the municipality of Guarapari are where the study took place (marked with mainland and island).

the plot, we then walked at least $5 \mathrm{~m}$ until we found another, different, vocalizing frog in a different patch (as described above) of bromeliads, at which time that point became the corner of a new plot. At the time of capture, we weighed (digital scale, $0.01 \mathrm{~g}$ precision) and measured snout-vent length (SVL, digital calipers, $0.1 \mathrm{~mm}$ precision) each frog at the capture location, where they were then released. We compared frog weight and SVL (both $\log _{10}$ transformed) between islands and the mainland using t-tests.

We compared bromeliad abundance and frog density (frogs per plant) between the mainland and the island using $\mathrm{G}$ tests. Statistical tests assumed an error probability of $5 \%$.

\section{RESULTS}

The island rule held, as predicted, with island frogs being heavier (mean $=1.02 \mathrm{~g}, \mathrm{SE}=0.10$, data back transformed from $\log _{10}$ values used in tests) and longer $(24.0 \mathrm{~mm}, \mathrm{SE}=0.1$, $\mathrm{n}=30)$ than mainland frogs $(0.74 \mathrm{~g}, \mathrm{SE}=0.10,21.0 \mathrm{~mm}, \mathrm{SE}=$ $0.1, \mathrm{n}=30$, weight: $\mathrm{t}=5.70$, SVL: $\mathrm{t}=7.60$, both $\mathrm{p}<0.01$, Fig. 2 ). We use linear regression between SVL and weight to illustrate the bivariate relationship $\left(\mathrm{F}_{1,58}=187.40, \mathrm{r}^{2}\right.$ adj $=0.76$, Fig. 2$)$.

Bromeliads in the sample plots were essentially equally abundant on the mainland (55, 92 and 116 per plot) and the island (50, 90 and 117 per plot) and no statistical test was nec- 


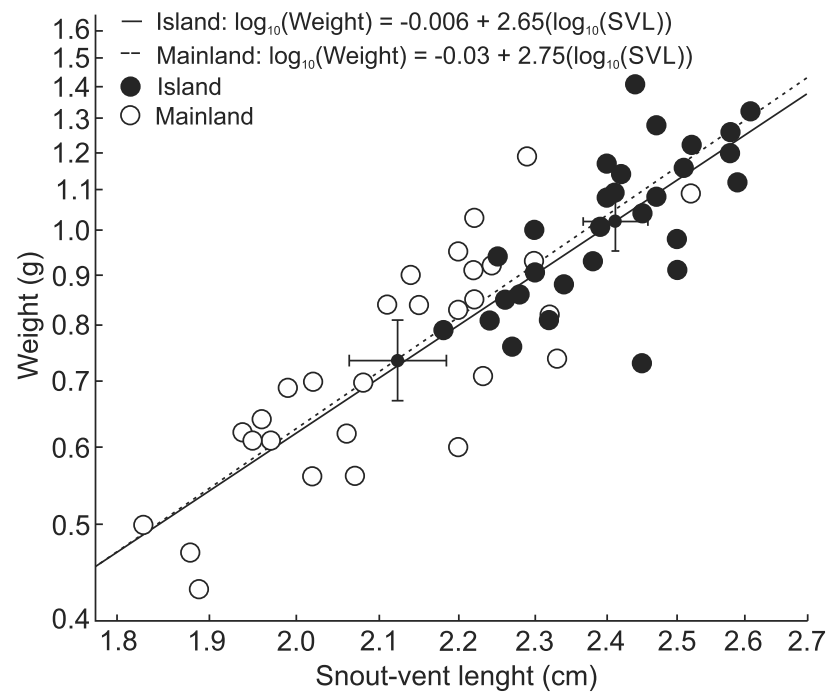

Figure 2. Scatterplot ( $\log _{10}$ scaled on both axes) of weight ( $\mathrm{g}$ ) by snout-vent length (SVL) on the mainland and island, illustrating variation found on each and that both tend to be greater on the island. The smaller symbols with error bars are the bivariate means with their $95 \%$ confidence intervals. We show the individual regression lines for illustrative purposes, while the two regressions were not statistically different (see text).

essary. Frogs, on the other hand, were much more abundant in the sample plots on the island $\left(109\right.$, or 1.45 individuals $\left.\mathrm{m}^{-2}\right)$ than plots on the mainland (20, or 0.26 individuals $\mathrm{m}^{-2}, \mathrm{G}=$ 56.4 , df $=1, \mathrm{p}<0.01$, Fig. 3). Combining density with body weight, biomass of frogs was 6.33 times greater on the island ( $3.48 \mathrm{~g} \mathrm{~m}^{-2}$ on the island and $0.55 \mathrm{~g} \mathrm{~m}^{-2}$ on the mainland).

On the mainland, frogs were found in four species of bromeliad: Aechmea blanchetiana (Baker) LB Sm., A. nudicaulis (L.) Griseb., Quesnelia quesneliana and Vriesea neoglutinosa Mez. In contrast, on the island, frogs were only found in two species: Q. quesneliana and Neoregelia cruenta (R. Graham) LB Smith. Thus, while bromeliads were similarly abundant in our study plots on the mainland and on the island, on the island one species (Q.quesneliana) was as abundant as the sum of the four species on the mainland.

\section{DISCUSSION}

Frogs on the island were larger (26\% heavier, 12\% longer) and much more abundant (5.5 times more in number, 6.3 times more in biomass) than on the mainland, thereby supporting the island rule in the frog, $P$. luteolus. The much greater abundance on the island than the mainland suggests that either resources are more available, predation is lower, or both, on the islands. Especially interspecific competition may be lower on the island because P. luteolus was the only frog species found in all the bromeliads that we searched on the island. On the

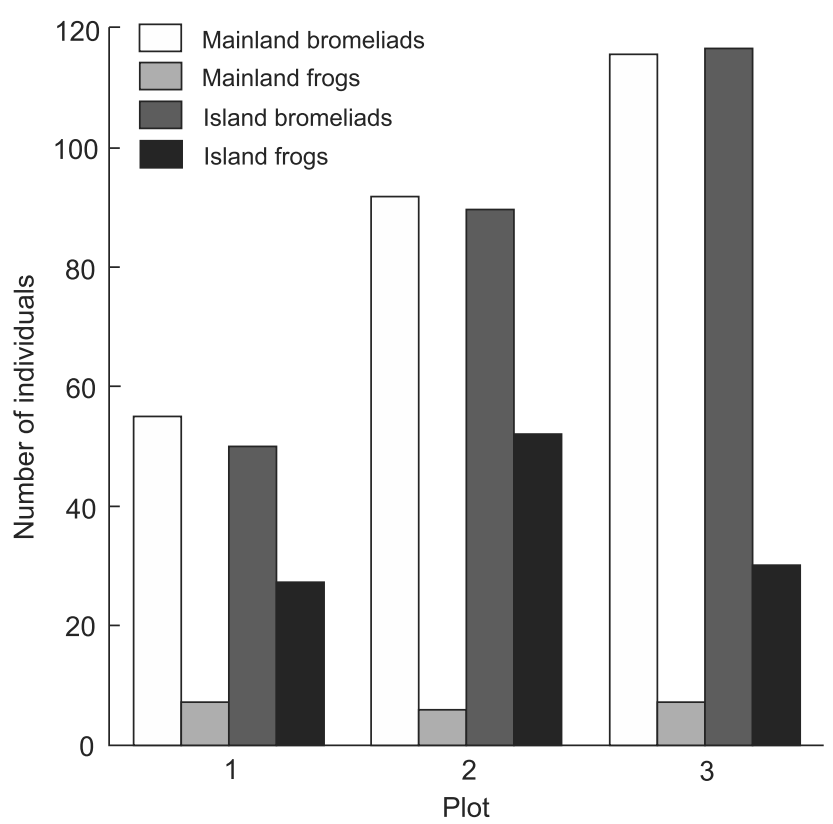

Figure 3. Comparison of the number of bromeliads (similar density on the island and mainland) and number of individuals of $P$. luteolus (more abundant on the island) by sampling plot on the island and the mainland.

mainland, however, we found Aparasphenodon brunoi MirandaRibeiro, 1920, SVL $\pm 80 \mathrm{~mm}$, Dendropsophus decipiens (Lutz, 1925), SVL $\pm 19 \mathrm{~mm}$, Rhinella crucifer (Wied-Neuwied, 1821), SVL $\pm 100 \mathrm{~mm}$, Hypsiboas semilineatus (Spix, 1824), SVL \pm 56 mm, Scinax alter (Lutz, 1973), SVL $\pm 28 \mathrm{~mm}$, and Scinax argyreornatus (Miranda-Ribeiro, 1926), SVL $\pm 21 \mathrm{~mm}$. Thus, while the island rule holds, the mechanism leading to increased size remains unclear, with some support for reduced competition. Understanding whether interspecific competition plays a role in community structure on the mainland would help clarify how P. luteolus responded on the island.

A similar tendency for increased size on islands was reported for Bufo viridis Laurenti, 1768, in Sardinia, Italy (CASTELLANO \& Giacoma 1998) and Rana limnocharis (Gravenhorst, 1829) in Zhoushan, China (Wu et al. 2006). However, exceptions occur, such as Rhinella ornata (Spix, 1824) (larger on the mainland) in Rio de Janeiro, Brazil (Montesinos et al. 2012). This difference between dwarfism and gigantism on islands and continents is probably due to the complex interaction between food, space and predation (Wu et al. 2006), but may also be explained by the size range of the animals in question. That is, larger frogs should get smaller, rather than merely assuming that frogs are all small and so should become larger on islands.

Increased size and abundance may occur when resources, such as food, shelter and breeding sites, are more available (Putman 1994, Hansson 1995). However, exactly how this interaction becomes manifest is unclear, because intraspecific com- 
petition may be even more important than interspecific competition, if resources are limiting. Thus, by increasing in abundance on the island, one would expect that intraspecific competition would also increase, thereby maintaining the small size of the frog. Greater species richness of frogs on the mainland may also generate much greater competition thereby causing a lower carrying capacity on the mainland relative to the island. By their absence on the islands, thereby eliminating interspecific competition, ecological release may have allowed the frogs to both increase in abundance and size (Lomolino 1985, Greenberg \& Danner 2013).

Also, if predation on the mainland keeps the population well under its carrying capacity, then ecological release on the island may simply result in a different equilibrium relationship between size and abundance as compared to the mainland. Amphibians are prey for many predators (Duellman \& Trueb 1994), including snakes (Bernarde \& Abe 2006, 2010, Bernarde 2012) and birds. While we did not search for potential predators, only a few species of vertebrates, including the lizard Tropidurus torquatus (Wied, 1820), the african gecko Hemidactylus mabouia (Moreau de Jonnès, 1818), the black rat Rattus rattus (Linnaeus, 1758), and marine birds were found on the island. During the study, we only encountered potential frog predators on the mainland, including snakes in Viperidae, Boidae and Colubridae. Thus, predation may be much lower on the island.

Our data support the island rule on islands off the coast of Brazil in the frog P. luteolus. The mechanisms through which size changes are unclear, but evidence and logic suggest that competition and predation are both important. Further study through capture and recapture methods could examine longevity on islands (due to reduced predation, frogs may simply live longer and longer-lived frogs are larger). Also, rearing frogs in a common garden experiment with unlimited resources can show whether this size difference is inherited or facultative. Evolution towards greater size can be rapid under certain conditions (Mathys \& Lockwood 2009) and here, the small Brazilian frog P. luteolus seems to be on the road to gigantism on the island. Mechanisms causing this increasing size should be tested and such tests will improve our understanding of evolution on islands as well as processes on the mainland.

\section{ACKNOWLEDGEMENTS}

We are grateful to Shai Meiri, Renato Feio and Rute Carvalho for their comments and great suggestions and Elaine Campinhos, Mariana Mageski, Rebeka Ferreira, Werther Krohling and Weslley Rangel for their help in the field. We thank the staff of the Parque Estadual Paulo Cesar Vinha for logistical support. We are grateful to the Instituto Estadual de Meio Ambiente (IEMA) and the Instituto Chico Mendes de Conservação da Biodiversidade (ICMBio, SISBIO) for permission (processes 59666501/2013 and $37762-2 / 2013$ respectively). MM received a scholarship from the Fundação de Amparo a Pesquisa do Estado do Espírito Santo
(FAPES) and Universidade Vila Velha (UVV) during the study. RBF received scholarships from Ecology Center at Utah State University and Conselho Nacional de Desenvolvimento Científico e Tecnológico (process 231020/2013-9). We also thank an anonymous reviewer for constructive and welcome suggestions and ideas to improve the quality of the text.

\section{LITERATURE CITED}

Benzie JA, Stoddart JA (1992) Genetic structure of crown-ofthorns starfish (Acanthaster planci) in Australia. Marine Biology 112: 631-639.

Bernarde PS, Abe AS (2006) A snake community at Espigão do Oeste, Rondônia, Southwestern Amazon, Brazil. South American Journal of Herpetology 1(2): 102-113. doi: 10.2994/1808-9798(2006)1[102:ASC AED]2.0.CO;2

Bernarde PS, Abe AS (2010) Hábitos alimentares de serpentes em Espigão do Oeste, Rondônia, Brasil. Biota Neotrópica 10(1): 167-173.

Bernarde PS (2012) Anfíbios e Répteis: introdução ao estudo da herpetofauna brasileira. Curitiba, Editora Anolis Books, 320p.

Bоваск, SM, Guyer C (2003) Empirical evidence for an optimal body size in snakes. Evolution 57(2): 345-351.

CASE TJ (1975) Species Numbers, Density Compensation, and Colonizing Ability of Lizards on Islands in the Gulf of California. Ecology 56: 3-18.

Castellano SA, Giacoma C (1998) Morphological variation of the green toad, Bufo viridis, in Italy: A test of causation. Journal of Herpetology 32(4): 540-550.

Clegg SM, Owens IPF (2002) The 'island rule' in birds: medium body size and its ecological explanation. Proceedings of the Royal Society B: Biological Sciences 269: 1359-1365. doi: $10.1098 /$ rspb.2002.2024

Cicchi PJP, Serafim H, Sena MA, Centeno FC, Jim J (2009) Herpetofauna em uma área de Floresta Atlântica na Ilha Anchieta, município de Ubatuba, sudeste do Brasil. Biota Neotropica 9(2): 201-212. doi: 10.1590/S1676-06032009000200019

Diamond JM (1970a) Ecological consequences of island colonization by southwest Pacific birds. I. Types of niche shifts. Proceedings of the National Academy of Sciences of United States of America 67: 529-536.

Diamond JM (1970b) Ecological consequences of island colonization by southwest Pacific birds. II. The effect of species diversity on total population density. Proceedings of the National Academy of Sciences of United States of America 67: 1715-1721.

Duellman We, Trueb L (1994). Biology of Amphibians. Baltimore, The Johns Hopkins University Press, 670p.

Foster JB (1964) The evolution of mammals of island. Nature 202: 234-235. doi: 10.1038/202234a0

Frost DR (2013) Amphibian Species of the World: an Online Reference. New York, American Museum of Natural History, 
electronic database, version 5.6. Available online at: http:/ /research.amnh.org/herpetology/amphibia/index.html [Accessed: 10/04/2014]

Greenberg R, DAnNer RM (2013) Climate, ecological release and bill dimorphism in an island songbird. Biology Letters 9(3): 20130118. doi: 10.1098/rsbl.2013.0118

Haddad CFB, Toledo LF, Prado CPA, Loebmann D, Gasparini JL, SAzIma I (2013) Guia de Anfíbios da Mata Atlântica: diversidade e biologia. São Paulo, Anolis Books Press, 544p.

HANsson S (1995) Effects of exploitative food competition on food niche dynamics - simulation analysis. Ecological Modeling 77(2-3): 167-187. doi: 10.1016/0304-3800(93)E0075-E

Hartl DL, Clark AG (2006) Principles of Population Genetics. Sunderland, Sinauer Associates, 565p.

Hopkins GR, Brodie EDJ, French SS (2014) Developmental and evolutionary history affect survival in stressful environments. PlosOne 9(4): 1-9.

Lomolino MV (1985) Body size of mammals on islands: the island rule reexamined. The American Naturalist 125(2): 310-316. doi: 10.1086/284343

Lomolino MV (2005) Body size evolution in insular vertebrates: generality of the island rule. Journal of Biogeography 32: 1683-1699.

Lomolino MV, SAx DF, Palombo MR, VAn Der Geer AA (2012) Of mice and mammoths: evaluations of causal explanations for body size evolution in insular mammals. Journal of Biogeography 39: 842-854.

Lossos JB, RickLefs RE (2010) The Theory of Island Biogeography, Revisited. Princeton, Princeton University Press, 476p.

MacArthur RH, DiAmond JM, KaRR JR (1972) Density compensation in island faunas. Ecology 53: 330-342.

Mathys BL, Lockwood JL (2009) Rapid evolution of great kiskadees on Bermuda: an assessment of the ability of the island rule to predict the direction of contemporary evolution in exotic vertebrates. Journal of Biogeography 36(12): 2204-2211. doi: 10.1111/j.1365-2699.2009.02169.x

MeIr S (2007) Size evolution in island lizards. Global Ecology and Biogeography 16: 702-708.

McGrady-Steed J, Morin PJ (2000). Biodiversity, density compensation, and the dynamics of populations and functional groups. Ecology 81: 361-373.
Montesinos R, Silva HR, Carvalho ALG (2012) The "island rule" acting on anuran populations (Bufonidae: Rhinella ornata) of the southern Hemisphere. Biotropica 44(4): 506-511. doi: 10.1111/j.1744-7429.2011.00835.x

Oliveira JCF, Rocha CFD (2015) Journal of coastal conservation: a review on the anurofauna of Brazil's sandy coastal plains. How much do we know about it? Journal of Coastal Conservation 19(1): 35-39.

Peiхото OL (1995) Associação de anuros a bromeliáceas na Mata Atlântica. Seropédica 17(2): 75-83.

Price T, Phillimore AB (2007) Reduced major axis regression and the island rule. Journal of Biogeography 34(11): 1998-1999. doi: 10.1111/j.1365-2699.2007.01796.x

Putman RJ (1994). Community Ecology. London, Chapman and Hal, 178p.

Raia P, Meiri S (2006) The island rule in large mammals: paleontology meets ecology. Evolution 60(8): 1731-1742. doi: $10.1554 / 05-664.1$

Salles ROL, Silva-Soares T (2010) Phyllodytes luteolus (Anura, Hylidae) as an Alien Species in the Rio de Janeiro municipality, State of Rio de Janeiro, Southeastern Brazil. Herpetology Notes 3: 257-258.

Silva-soares T, Hepp F, Costa PN, Luna-Dias C, Gomes Mr, CarvaLHO-E-Silva AMPT, CarvalHo-e-SILVA SP (2010) Anfíbios anuros da RPPN Campo Escoteiro Geraldo Hugo Nunes, Município de Guapimirim, Rio de Janeiro, Sudeste do Brasil. Biota Neotropica 10(2): 225-233.

Valdujo PH, Camacho A, Recoder RS, Teixeira Junior M, Ghellere JM, Mott T, Nunes PMS, Nogueira C, Rodrigues MT (2011) Anfíbios da Estação Ecológica Serra Geral do Tocantins, região do Jalapão, Estados do Tocantins e Bahia. Biota Neotropica 11(1): 251-261.

VAN VAlen L (1973) Pattern and the balance of nature. Evolutionary Theory 1: 31-49.

Whittaker RJ, Fernández-PaLAcios JM (2007) Island Biogeography. Oxford, University Press, 401p.

WRIGHT SJ (1980) Density compensation in island avifaunas. Oecologia 45: 384-389.

WU Z, LI Y, MurRAY BR (2006) Insular shifts in body size of rice frogs in the Zhoushan Archipelago, China. Journal of Animal Ecology 75(5): 1071-1080.

Submitted: 17 January 2015

Received in revised form: 26 August 2015

Accepted: 21 September 2015

Editorial responsibility: Mauricio O. Moura 